\title{
Eco-Histopathology of Nile Tilapia (Oreochromis niloticus) and African Catfish (Clarias gariepinus) From Industrially Contaminated Locations of Ologe Lagoon, South-Western, Nigeria
}

\author{
Akintade O. Adeboyejo ${ }^{1}$, Adedapo O. Fagbenro ${ }^{2}$, Yemisi E. Adeparusi ${ }^{2}$, Edwin O. Clarke ${ }^{1}$, Oladidupo Lawal ${ }^{3}$, \\ Albert O. Amosu ${ }^{4} \&$ Olalekan W. Bashorun ${ }^{5}$ \\ ${ }^{1}$ Department of Fisheries, Faculty of Science, Lagos State University, Ojo, Lagos, Nigeria \\ ${ }^{2}$ Department of Fisheries and Aquaculture, School of Agriculture and Agricultural Technology, (FUTA) Akure, \\ Nigeria \\ ${ }^{3}$ Department of Chemistry, Faculty of Science, Lagos State University, Ojo, Lagos, Nigeria \\ ${ }^{4}$ Department of Biodiversity and Conservation Biology, Faculty of Natural Science, University of the Western \\ Cape, Cape Town, South-Africa \\ ${ }^{5}$ Department of Agricultural Science, School of Vocational \& Technical Education, Adeniran Ogunsaya College \\ of Education, Otto/Ijanikin, PMB 007 Feastac Town, Lagos, Nigeria
}

Correspondence: Akintade O. Adeboyejo, Department of Fisheries, Faculty of Science, Lagos State University, Ojo, Lagos, Nigeria. E-mail: adeboyejoakintade@yahoo.co.uk

Received: September 6, 2012 Accepted: January 20, 2013 Online Published: January 24, 2013

doi:10.5539/enrr.v3n2p28

URL: http://dx.doi.org/10.5539/enrr.v3n2p28

\begin{abstract}
A study was carried out to assess the physico-chemical, heavy-metals parameter and Histopathology of adult fish specimen of Oreochromis niloticus and Clarias gariepinus collected from effluents sources of Ologe lagoon. The aim of the study is to assess the impact of industrial effluents on the lagoon, and on the health of resident fish fauna. 5 sample stations were marked out. Water samples were collected in triplicates; once every two months from each sample station. Effluent samples from the three point sources were also analyzed. Mean values for physico-chemical parameters, heavy-metals and three other effluent sources monitored ranges are $\mathrm{pH}$, $6.17 \pm 0.42-10.25 \pm 1.18$, DO, $1.18 \pm 0.50-6.13 \pm 1.03 \mathrm{mg} / \mathrm{l}$, TDS, 86.6 $\pm 19.17-621.97 \pm 16.22 \mathrm{mg} / \mathrm{l}$, hardness, ND-58.03 $\pm 0.90 \mathrm{mg} / \mathrm{l}$, alkalinity, $22.06 \pm 8.08-352.37 \pm 14.58 \mathrm{mg} / 1, \mathrm{Cl}^{-1}, 31.09 \pm 18.16-268.98 \pm 31.41 \mathrm{mg} / \mathrm{l}$, acidity, ND-73.73 $\pm 13.00 \mathrm{mg} / \mathrm{l}, \mathrm{Zn}, 0.07 \pm 0.01-0.65 \pm 0.18 \mathrm{mg} / \mathrm{l}, \mathrm{Fe}, \mathrm{ND}-1.40 \pm 0.50 \mathrm{mg} / \mathrm{l}, \mathrm{Cu}, 0.001 \pm 0.001-0.53 \pm 0.36 \mathrm{mg} / \mathrm{l}$ $\mathrm{Cd}, \mathrm{ND}-0.07 \pm 0.02 \mathrm{mg} / \mathrm{l}$, and Pb, ND-10.15 $\pm 21.83 \mathrm{mg} / \mathrm{l}$. Several live lesions have been observed in the study as tissue bio-makers consistent with the exposure of fish to effluent. These include pigmented macrophage aggregation, hepatocytes vacoulation, multi foci coagulative necrosis and liver fatty degeneration. The preponderance of these lesions in fish from contaminated waters bordering urban locations similar to our test location has been firmly established and described by other researchers. Therefore, the extent of deformities and cell injuries is as a result of toxicant actions of the industrial effluents.
\end{abstract}

Keywords: histopathology, physico-chemical, fish fauna, Ologe lagoon, effluents and contamination

\section{Introduction}

Histopathology provides a sensitive indicator of stress induced by industrial effluents. Due to the central role of organs in the transformation of several chemical active compounds into aquatic environment, the teleost gills, kidney and liver has been the foci of toxicology studies and has indeed been shown to be very sensitive to pollutant exposure (Pinkney, 2004). Pathological changes resulting as consequences due to exposure to certain chemicals, especially Poly Aromatic Hydrocarbons (PAHs), regarded as characteristics have been included in the definitions of beneficial use impairment criteria (Blazer, 2007). Relevant aquatic pollution sources in Nigeria in particular, Lagos being the commercial capital with its great (and ever growing) population and industries include: pesticides, plastic wastes, myriad industrial effluents, sawmill and pulp industry, runoffs and shipping ballast.

Heavy metals have long been recognized as serious pollutants of the aquatic environment, they cause serious 
impairment in metabolic, physiological and structural system when present in high concentration as opined by Javed (2003). Heavy metals may affect organisms directly by accumulating in their body or indirectly by transferring to the next trophic level of the food chain. Trace metals are introduced into the environment by a wide spectrum of natural and anthropogenic sources. Metals are non-biodegradable and once they enter the environment, bio-concentration may occur in fish tissues by means of metabolic and bio-absorption processes (Hogstrand \& Haux, 1991).

However, in fish living in water bodies receiving high discharges of effluent from industries, a range of alterations related to physiological abnormalities have been observed (Tyler et al., 1998; Vethaak et al., 2002). These effects have been attributed to various estrogenic chemicals known to be present within treated or/and untreated industrial effluents. Indeed, extensive laboratory-based studies have confirmed that chemicals contained in industrial effluents can induce many effects (Seki et al., 2002; Jobling et al., 2006). Furthermore, it has been shown that exposure to industrial effluents can inhibit the reproduction of fish (Seki et al., 2002; Parrott \& Blunt, 2005; Harries et al., 2000; Kang et al., 2003; Thorpe et al., 2007). Although, the concentrations of chemicals typically measured in Waste water, treated or un-treated effluents may be low, compared to those required to affect fish reproduction in short-term laboratory studies, there are still major concerns about long-term exposures to effluents. This is because a prolonged exposure to some of these chemicals increases their level of effect (Thorpe et al., 2001, 2003). Specific studies that directly assess the effects of industrial effluents on population-relevant end-points, such as fish seed production (fingerlings/juveniles), are therefore, required to understand the consequence of exposure; relative to their histopathology, physiology, growth and survival.

Ologe lagoon is used for fishery, waste disposal, sand mining and transportation. As with other lagoons within the Lagos lagoon complex (Figure 1), it is also regarded as the 'large septic tank' in the region. The main anthropogenic pressure on Ologe lagoon is from the adjacent Agbara industrial estate, where over 20 factories belonging to: food and beverages, pharmaceutical, breweries, metal finishing industries, chemical and pulp and paper companies presently occupy the industrial area. The effluents of these industries are discharged in the lagoon all year round, with their immediate impacts on the ecology of the lagoon system. Ologe lagoon drains into the Atlantic Ocean through the Badagry creek and through the Lagos harbour. Ologe lagoon is of great importance not only to Lagos state and Nigeria, but to the entire West-African sub-region as ecological catastrophes occurring upstream, could have severe consequences downstream if unchecked. This research work was an attempted to determine the significance and severity of lesions observed in fish tissues, liver and gills relative to the contaminated aquatic locations of the study area and due to dearth of relevant pathological data relating anthropogenic input to the aquatic environment and fish health. The test species, Oreochromis niloticus and Clarias gariepinus were selected for use as a local sentinel species for the investigation of the impact of brackish water industrial pollutants on fish on the basis of their ubiquitousness, prolificacy, and market potentials in Nigeria.

\section{Materials \& Methods}

\subsection{Study Area}

The study area is within the Lagos lagoon complex, covering about $6354.71 \mathrm{~km}^{2}$ in area and $285 \mathrm{~km}$ in perimeter, is a brackish coastal water bounding the city of Lagos, lying between $6^{\circ} 27^{\prime}-37^{\prime} \mathrm{N}$ and $3^{\circ} 02-3^{\circ} 09^{\prime} \mathrm{E}$ (Clarke et al., 2008). The lagoon cuts across the southern part of the Lagos metropolis, linking the Atlantic Ocean (in the west and south) and Lekki lagoon (in the east). It is fairly flat, approximately above sea level, swampy area to the south east. It serves severally as a place of abode, recreation, livelihood and transport for fisher folk and is a dumpsite for residence, industries, and for other wastewaters. 


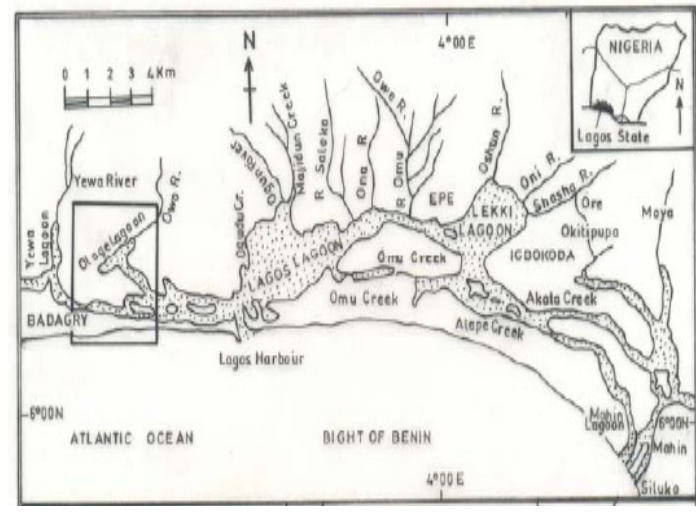

Figure 1. Map of Lagos Lagoon - Inset Ologe Lagoon

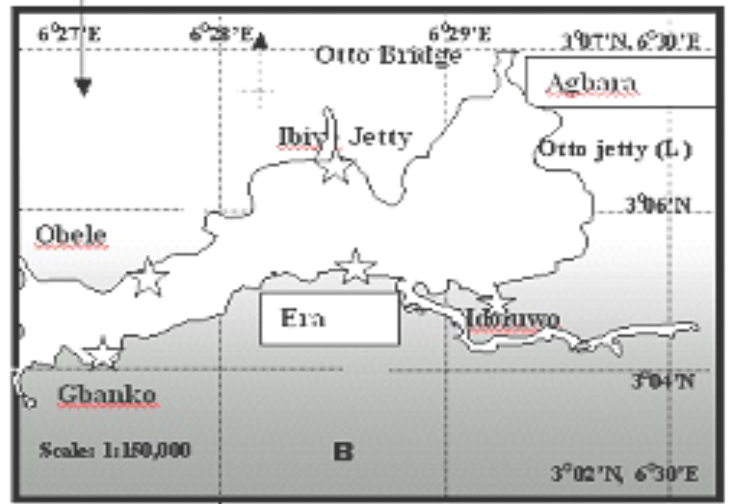

Figure 2. Map of Ologe Lagoon showing sampling stations (*). Source: Clarke, 2009

\subsection{Specimen Collection}

A total of 400 specimens of Oreochromis niloticus and Clarias gariepinus were collected at Ologe lagoon. The fish were collected in the early hour of the day live to avoid heat exertion and suffocation. They were then brought to the Lagos State University Fisheries laboratory so as to collect or extract the organs needed; and labelled. The external appearance of the fish indicated few abnormalities. No sex selection was made. The fish were sacrificed by a pre-occipital severance of the spinal cord. Each specimen was weighed, the total and standard length were recorded. They were then dissected, the liver, tissues, hearth and gills excised. These were then examined using hand lens, to detect the presence of gross lesions.

\subsection{Water Quality Parameter}

Water samples were taken once in two months between January-November (2011) and this was with respect to five (5) sample stations in the study area (Ologe lagoon). The sample stations were plotted to traverse the whole lagoon area, these are Obele, Gbanko, Idolowu, Ibiye jetty and Otto jetty. These are also represented in Figure 2. The physical and chemical characteristic of the effluent were determined using standard methods (APHA, 1998), and the heavy-metal contents using the Atomic Absorption Spectrophotometer (AAS). The following parameters were analyzed: The temperature was measured with mercury in bulb thermometer. The thermometer is immersed in the water sample for 2-3 minutes and the values thus recorded. The measurements were taken three times and the average value recorded. An Orion $\mathrm{pH}$ meter (model $407 \mathrm{~A}$ ) was used in the measurement of $\mathrm{pH}$ levels. The $\mathrm{pH}$ meter was calibrated using reference buffer solutions of 4.0 to 9.2 ranges. The purpose of calibrating or standardizing the $\mathrm{pH}$ meter with standard buffer solution is usually to ensure the linearity of the meter. The test solution was stirred during the period of $\mathrm{pH}$ measurement. Successive portions of the test solution were measured, until readings of two successive portions differ with less than 0.02. Dissolved Oxygen (DO) was determined using the Winkler's method in which $0.5 \mathrm{ml}$ of $\mathrm{MnSO}_{4}$ solution and $0.5 \mathrm{ml}$ alkaline Iodide reagent was added to the test solution well below the surface of the liquid in a sampling bottle. This was then mixed by inverting the bottle a few times resulting in a precipitate which settles at the bottom. Then $0.5 \mathrm{ml}$ of concentrated $\mathrm{H}_{2} \mathrm{SO}_{4}$ was added, stopped and mixed by gentle inversion. This solution was then titrated with $0.025 \mathrm{~N}$ Thiosulphate. 1-2 ml freshly prepared starch solution was added until a titre value is obtained and then used to get the amount of oxygen. Total Dissolved Solid (TDS) was measured by evaporating the sample to a small volume and transferred to a weighed basin where the sample was dried at $105^{\circ} \mathrm{C}$ to constant weight. The residue was cooled in a desiccator and weighed. Alkalinity was determined using titration method. $25 \mathrm{ml}$ of test sample was titrated with $0.02 \mathrm{~N} \mathrm{H}_{2} \mathrm{SO}_{4}$. One or two drops of methyl orange was added until a titre value is obtained. The value was used to calculate the alkalinity.

\subsection{Heavy Metals Determination}

Heavy metals determination was done in test materials (according to APHA, 1998) by atomic absorption spectrophotometric methods (Perkins Elmer AAS model 3110). The samples were prepared by wet digestion methods. In a $500 \mathrm{ml}$ Taylor flask, $0.5 \mathrm{ml}$ of concentrated $\mathrm{H}_{2} \mathrm{SO}_{4}$ was added to $100 \mathrm{ml}$ of sample. This was allowed to boil down to the white fume stage. The solution was allowed to cool; $1 \mathrm{ml}$ of $60 \% \mathrm{HCLO}_{4}$ and $5 \mathrm{ml}$ conc. $\mathrm{HNO}_{3}$ was added and digested until clear. Also, a blank was digested in the same way. The prepared samples was then diluted to appropriate volume and read in the AAS. Zinc standard was obtained by preparing a 
stock solution $\left(0.4398 \mathrm{~g} \mathrm{ZnSO}_{4} \cdot 7 \mathrm{H}_{2} \mathrm{O}\right.$ in water and made up to I litre). The standard solution was diluted to give a range of 0-5 ppm $\mathrm{Zn}$ which was used as the working standard. The prepared sample was diluted as appropriate and read on the AAS using $213.8 \mathrm{~nm}$ wavelength. A calibration curve was prepared from standard range and Zinc concentration was obtained. Chromium $(\mathrm{Cr})$ Standard was prepared, from the stock solution $(1 \mathrm{ml}=1 \mathrm{mg}$ Cr) by dissolving $2.82 \mathrm{~g} \mathrm{k}_{2} \mathrm{Cr}_{2} \mathrm{O}_{7}$ in water and made up to a litre. A working range of $0-2 \mathrm{ppm} \mathrm{Cr}$ was used and $357.9 \mathrm{~nm}$ wavelength was selected. The acetylene and air flow and other settings as specified were adjusted. A calibration curve was prepared from the standard readings and was used to calculate the chromium concentration. Lead standard was prepared from the stock solution $100 \mathrm{ppm} \mathrm{Pb}$ ) by dissolving $0.1599 \mathrm{~g} \mathrm{PbCNo}_{3}$ in $20 \mathrm{ml} 1 \%$ $\mathrm{v} / \mathrm{v} \mathrm{HNO}_{3}$ and made up to 1 litre. A working range of $0-100 \mathrm{ppm} \mathrm{Pb}$ was prepared by diluting the stock solution and including the acid as appropriate to match the sample condition. The lead concentration was read by selecting $283.3 \mathrm{~nm}$ wavelength. The acetylene and airflow was adjusted and a calibration curve was prepared. Chloride was measured using the agentometric method. The water sample was titrated against silver nitrate solution $\left(\mathrm{AgNO}_{3}\right)$ using $10 \%$ potassium chromate solution as indicator. Titre value was equivalent to the amount of chloride presents.

\subsection{Histopathology}

Liver and gills samples of each specimen were fixed with $10 \%$ formalin in phosphate buffer for 36 hours. Care was taken so that onset of fixation was immediately post excision. Fixed specimen were taken to the Veterinary Pathology Laboratory of the University of Ibadan, Nigeria where they were dehydrated in graded ethanol and then transferred into Xylene for five minutes preparatory to embedding in paraffin. Liver and gills samples were then embedded in paraffin and histological sectioning subsequently done at $5 \mu \mathrm{m}$ using a $\mathrm{TBS}^{\circledR} \mathrm{CUT}^{\mathrm{TM}}$ rotary microtome. Sections were randomly done but care was taken to ensure that a large as possible area of the liver and gills were sectioned. Resulting sections were mounted on glass microscope slide and air-dried prior to staining using Haematoxylin and Eosin stain and cover slipped (Neskovic et al., 1996). Stained sections were analyzed using light microscope. Obtained sections were carefully observed under high magnification microscope at x 350 and x 450 magnification, for the presence and qualification of detectable stromal and parenchymal derangements including (but not limited to): 1. Vacoulation 2. Macrophage aggregation 3. Biliary duct proliferation and 4. Neoplasia. Various regions of each of the organs were section to keep the investigative process as accurate as possible.

\section{Results}

\subsection{Water Quality Parameters}

Summary of the results is reported in Table 1, this shows that $\mathrm{pH}$ ranged between 11.7-11.93 being an alkaline environment, dissolved oxygen (DO) was between $4.96-10.06 \mathrm{mg} / \mathrm{l}$, Chemical oxygen demand (COD) range between 203.5-1356.8 mg/l, biological oxygen demand (BOD) was between 37.68-56.7 mg/l, etc. These values were indicative for the peak of dry season in the lagoon. During the peak of raining season, as evident in July, $\mathrm{pH}$ give changed to a better environmental condition as a result of rain dilution of effluents, DO was between 3.76-5.3 mg/l, COD range between $302.5-1356.8 \mathrm{mg} / 1$ showing constant level chemical pollutants in the environment and are not easily degradable, while BOD was between $38.71-49.82 \mathrm{mg} / \mathrm{l}$ which shows that organic compound are bio-degradable at the peak of rainfall. Heavy-metal values in Ologe lagoon were also represented in the tables 1: $\mathrm{Zn}$; which is one of the pollutants, was detected in the water samples with values ranging from $0.94-1.62 \mathrm{mg} / \mathrm{l}$, Ni was between 0.44-41.51 mg/l, Al ranged between 21.61-196.86 mg/l, Cr ranged from $0.84-3.22 \mathrm{mg} / 1$, Cu ranged from $0.22-1.15 \mathrm{mg} / 1$, but lead was not detected during the dry season. Conversely, the wet season present an interesting range of data with zinc ranging between $0.56-1.54 \mathrm{mg} / \mathrm{l}$, Ni was between $0.18-0.99 \mathrm{mg} / \mathrm{l}$, Aluminium ranged between 183.63-199.99 mg/l, Cr ranged from 1.68-2.89 mg/l, Cu ranged from 0.49-0.61 $\mathrm{mg} / \mathrm{l}$, and lead range between 0.18-0.30 during the wet season.

Table 1. Water Quality parameter within the period of study (2011) in Ologe Lagoon

\begin{tabular}{lllllll}
\hline Parameter & Jan. & March & May & July & Sep. & Nov. \\
\hline PH & $11.82 \pm 0.09$ & $10.95 \pm 0.06$ & $9.55 \pm 0.41$ & $10.88 \pm 0.77$ & $9.53 \pm 1.19$ & $8.62 \pm 0.39$ \\
Dissolved Oxygen (mg/l) & $7.35 \pm 2.70$ & $5.69 \pm 1.76$ & $6.04 \pm 0.78$ & $7.3 \pm 2.7$ & $5.69 \pm 1.76$ & $4.68 \pm 0.65$ \\
Total Dissolved Solid (TDS) (mg/l) & $273.5 \pm 15.75$ & $166.75 \pm 26.86$ & $628.5 \pm 29.63$ & $280.25 \pm 18.01$ & $376.25 \pm 40.39$ & $430.5 \pm 62.55$ \\
Chemical Oxygen Demand (mg/l) & $623.28 \pm 06.1$ & $265.01 \pm 56.02$ & $226.85 \pm 51.08$ & $621.14 \pm 35.52$ & $1216.9 \pm 23.68$ & $648.3 \pm 40.59$ \\
\hline
\end{tabular}




\begin{tabular}{lllllll}
\hline Biological Oxygen Demand (mg/l) & $49.19 \pm 8.38$ & $166.75 \pm 0.26$ & $49.11 \pm 7.76$ & $51.62 \pm 13.76$ & $52.92 \pm 4.71$ & $42.54 \pm 5.02$ \\
Total alkalinity (mg/l) & $24.14 \pm 2.56$ & $265.01 \pm 2.90$ & $25.75 \pm 1.65$ & $24.43 \pm 2.12$ & $491.3 \pm 952.47$ & $18.19 \pm 0.80$ \\
Chloride (mg/l) & $235.00 \pm 23.2$ & $21.62 \pm 2.49$ & $84.79 \pm 48.93$ & $39.98 \pm 43.26$ & $690.77 \pm 24.99$ & $775.1 \pm 155.1$ \\
Zinc (mg/l) & $1.62 \pm 0.51$ & $0.43 \pm 571.98$ & $0.56 \pm 0.01$ & $0.89 \pm 0.21$ & $0.67 \pm 0.12$ & $0.83 \pm 0.48$ \\
Nickel (mg/l) & $0.52 \pm 0.18$ & $41.51 \pm 0.53$ & $0.44 \pm 0.04$ & $0.54 \pm 0.12$ & $0.69 \pm 0.20$ & $0.73 \pm 0.38$ \\
Aluminium (mg/l) & $185.14 \pm 11.4$ & $21.61 \pm 0.04$ & $196.86 \pm 5.95$ & $185.55 \pm 9.64$ & $186.15 \pm 5.27$ & $192.05 \pm 6.76$ \\
Chromium (mg/l) & $2.24 \pm 1.05$ & $390.25 \pm 2.18$ & $0.63 \pm 0.19$ & $1.18 \pm 0.90$ & $1.42 \pm 0.34$ & $1.99 \pm 0.60$ \\
Cupper (mg/l) & $0.57 \pm 0.41$ & $1.15 \pm 0.03$ & $0.22 \pm 0.03$ & $0.33 \pm 0.28$ & $0.42 \pm 0.14$ & $0.53 \pm 0.05$ \\
Lead (mg/l) & $\mathrm{ND}$ & $0.60 \pm 0.03$ & $0.21 \pm 0.23$ & $0.49 \pm 0.06$ & $\mathrm{ND}$ & $0.25 \pm 0.06$ \\
\hline
\end{tabular}

Note: ND = Not detected.

The comparison of results of physicochemical parameters and heavy-metals amongst Ologe lagoon, effluents from breweries, soft drink industry, hotels and Federal Ministry of Environment standards (FME) are presented in Table 2. $\mathrm{pH}$ from Ologe lagoon was highest (10.25 \pm 1.18$)$, while others were slightly acidic especially from soft drink industry (6.17 \pm 0.42$)$. The result showed that dissolved oxygen (DO) was the most severed parameter, with the lowest mean DO concentration of $1.18 \pm 0.05$ (from Breweries industry) when compared with overall mean value from Ologe lagoon $(6.13 \pm 1.03)$.

\subsection{Histopathology}

Microscopic examinations are shown in Plate 1-6 (at x350). These shows condition of diseases or abnormalities in the gills and liver being bio-makers of industrial influx in the aquatic environment having strong pathotoxic effects on the resident specimens. Hepatic perivascular mono-nuclear cell infiltration and necrosis in Clarias gariepinus, multi-focal coagulative necrosis of the hepatocytes, and hepatic fatty degeneration in Oreochromis niloticus ranging from mild to severe were a relatively consistent findings with the majority of the observed lesions occurring in the livers from Ologe lagoon (Plate 3, 4, 5, and Plate 6). However in the gill, there were cases of severe gill lamella necrosis and degeneration (as shown in Plate 1 and 2).

Table 2. Comparative mean values of physico-chemical and heavy-metals parameter of Ologe lagoon and three other effluent sources

\begin{tabular}{llllll}
\hline Parameters & Ologe lagoon & Breweries & Soft drinks & Hotels & FME Standards \\
\hline $\mathrm{pH}$ & $10.25 \pm 1.18$ & $7.62 \pm 0.07$ & $6.17 \pm 0.42$ & $6.77 \pm 0.32$ & $6.0-9.0$ \\
$\mathrm{DO}(\mathrm{mg} / \mathrm{l})$ & $6.13 \pm 1.03$ & $1.18 \pm 0.50$ & $3.2 \pm 0.10$ & $1.34 \pm 0.00$ & $>2$ \\
$\mathrm{TDS}(\mathrm{mg} / \mathrm{l})$ & $359.29 \pm 10.32$ & $569.58 \pm 17.56$ & $86.6 \pm 19.17$ & $621.97 \pm 16.22$ & 1000 \\
Hardness $(\mathrm{mg} / \mathrm{l})$ & $\mathrm{ND}$ & $42.32 \pm 11.63$ & $12.53 \pm 1.53$ & $58.03 \pm 0.90$ & - \\
$\mathrm{Alkalinity}(\mathrm{mg} / \mathrm{l})$ & $176.6 \pm 10.4$ & $88.04 \pm 19.48$ & $22.06 \pm 8.08$ & $352.37 \pm 14.58$ & $30-50$ \\
$\mathrm{Cl}-(\mathrm{mg} / \mathrm{l})$ & $268.98 \pm 31.41$ & $189.37 \pm 11.87$ & $31.09 \pm 18.16$ & $156.87 \pm 33 . \mathrm{I} 5$ & 250 \\
$\mathrm{Acidity}(\mathrm{mg} / \mathrm{l})$ & $\mathrm{ND}$ & $71.80 \pm 14.43$ & $73.73 \pm 13.00$ & $\mathrm{ND}$ & - \\
$\mathrm{Zn}(\mathrm{mg} / \mathrm{l})$ & $0.65 \pm 0.18$ & $0.35 \pm 0.12$ & $0.63 \pm 0.40$ & $0.07 \pm 0.01$ & $<1$ \\
$\mathrm{Iron}, \mathrm{mg} / \mathrm{L}$ & $\mathrm{ND}$ & $1.40 \pm 0.50$ & $0.35 \pm 0.05$ & $0.32 \pm 0.05$ & 20 \\
$\mathrm{Cu}(\mathrm{mg} / \mathrm{l})$ & $0.53 \pm 0.36$ & $0.23 \pm 0.31$ & $0.02 \pm 0.00$ & $0.001 \pm 0.001$ & $<1$ \\
$\mathrm{Cd}(\mathrm{mg} / \mathrm{l})$ & $\mathrm{ND}$ & $0.01 \pm 0.04$ & $0.07 \pm 0.02$ & $\mathrm{ND}$ & $<1$ \\
$\mathrm{~Pb}(\mathrm{mg} / \mathrm{l})$ & $0.38 \pm 21.83$ & $\mathrm{ND}$ & $\mathrm{ND}$ & $\mathrm{ND}$ & $<1$ \\
\hline
\end{tabular}

$\mathrm{ND}=$ Not Detected. FME $=$ Federal Ministry of Environment. FME source: FEPA, 1999. 


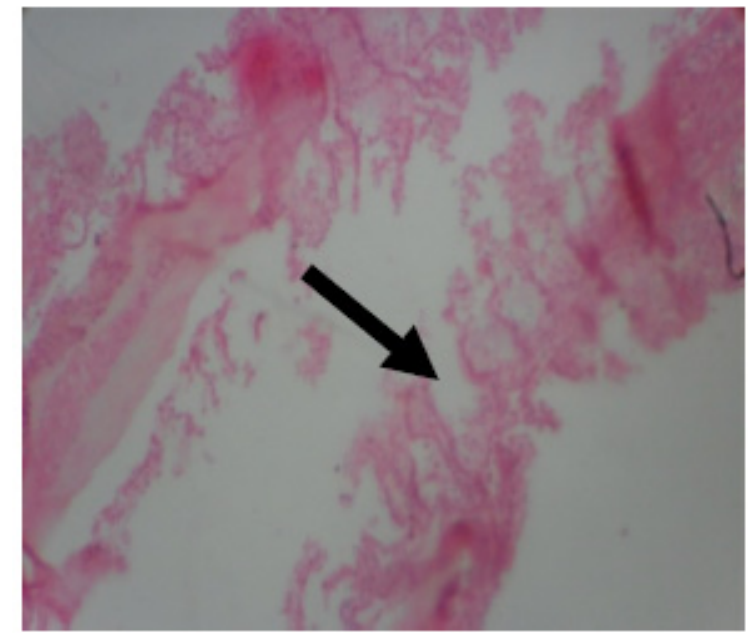

Plate 1. Gill showing severe gills lamella (arrows) necrosis and Degeneration in C. gariepinus

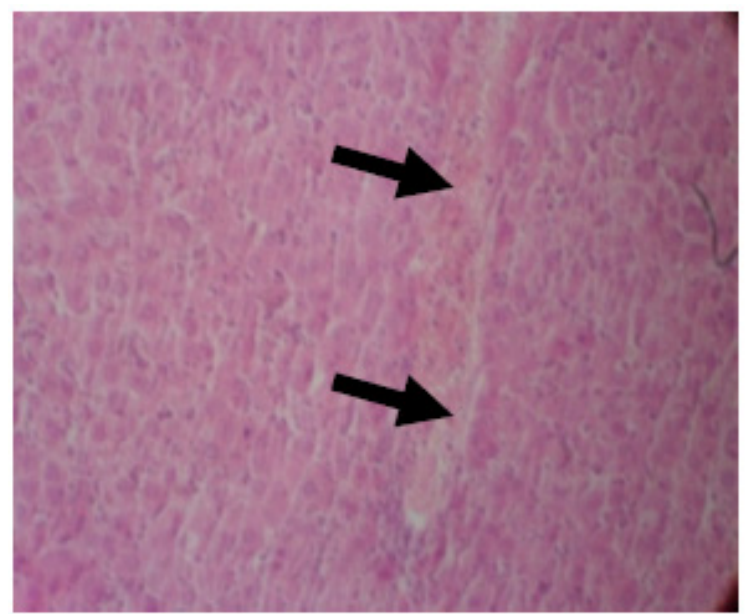

Plate 3. Liver tissues in C. gariepinus showing areas of coagulative necrosis

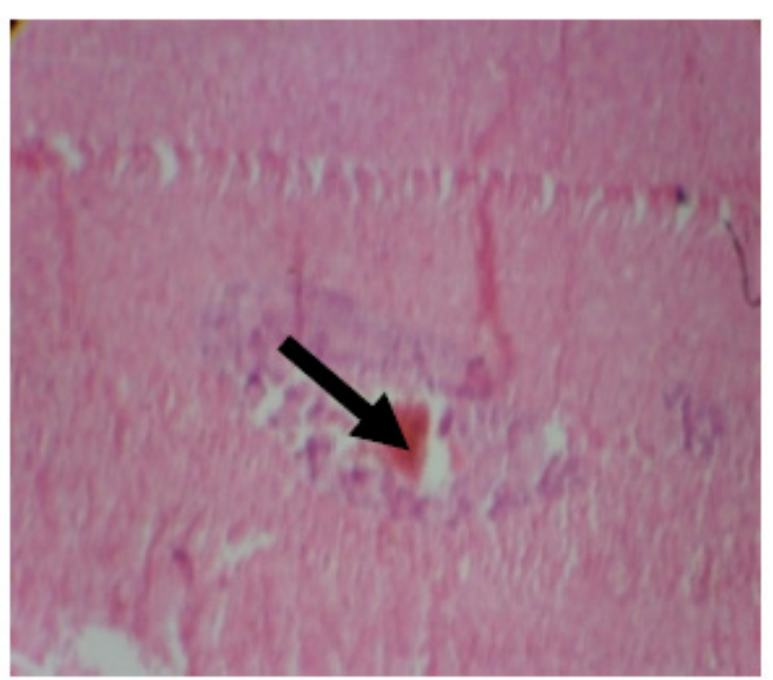

Plate 5. Liver of $C$. gariepinus with perivascular coagulative necrosis $(\mathrm{x} 450)$

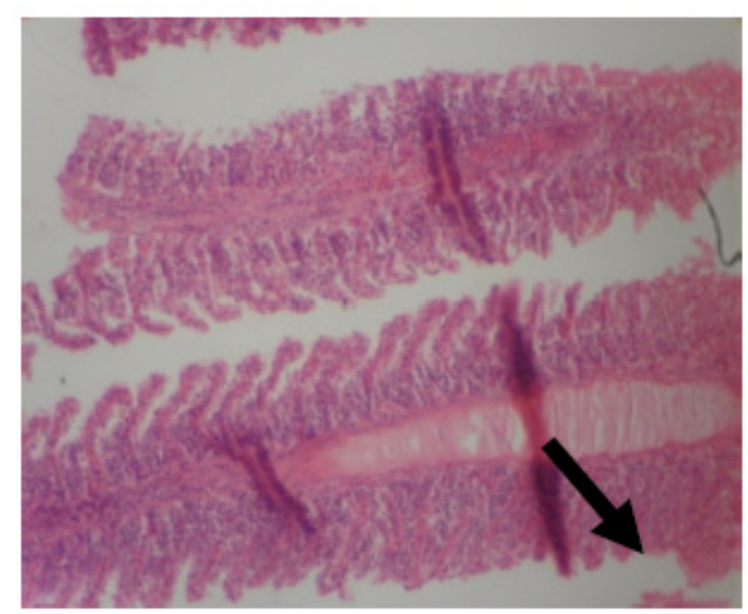

Plate 2. Gill showing severe gill lamella necrosis and degeneration In Oreochromis niloticus

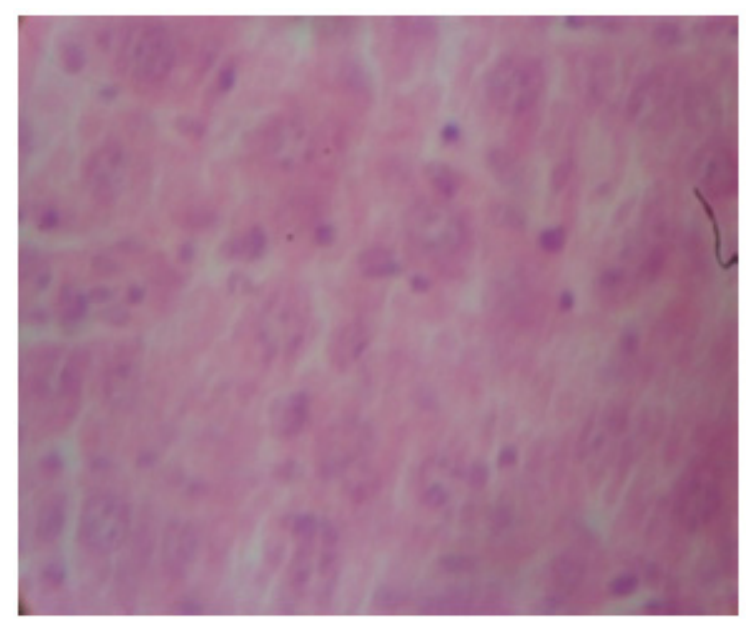

Plate 4. Liver showing perivascular mono-nuclear cell Infiltration and Vacoulation (x350) in $O$. niloticus

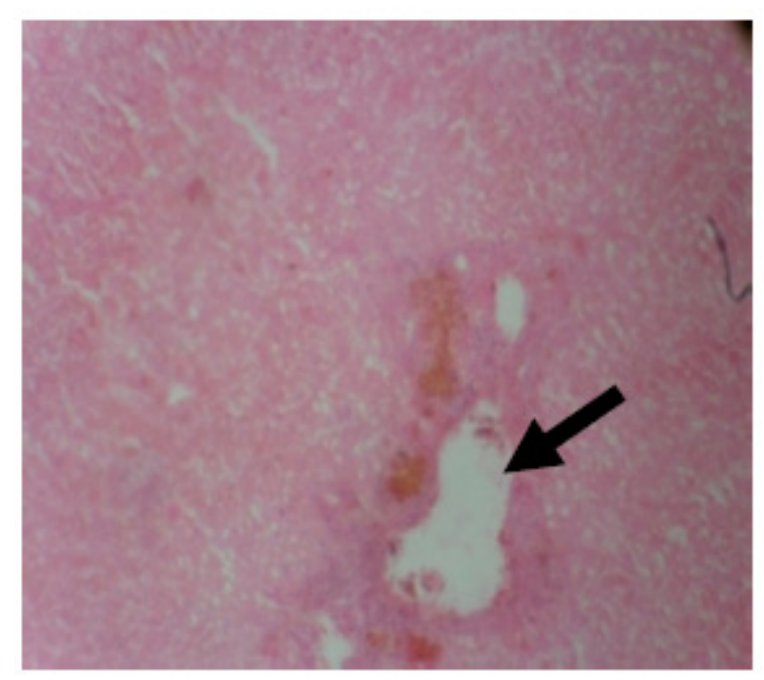

Plate 6. Severe Liver fatty (arrows) degeneration in O. niloticus (x350) 


\section{Discussion}

Metabolic rate and physiological processes are controlled by water temperature. As metabolic activities increase with an increase in temperature, fish demand for oxygen increases. In this study, The mean dissolved oxygen of $6.13 \mathrm{mg} / \mathrm{l}$ recorded for the sampling stations buttressed the recommendation of the Federal Ministry of Environment, that DO level of 3-4 mg/l is required for fish growth. This is also supported by Agboola et al. (2008) and Adeboyejo et al. (2009) who reported the mean DO level of $4.81 \mathrm{mg} / 1$ in Badagry creek and $4.5 \mathrm{mg} / 1$ in Kuramo lagoon, Nigeria respectively. Comparatively, the DO level in Ologe lagoon is well above the minimum $5.0 \mathrm{mg} / 1$ suggested by Awosika et al. (2002) and the $6.0 \mathrm{mg} / 1$ standard suggested by FEPA (1999) for the survival of fish and other aquatic organisms. However Dissolved oxygen remained slightly stable throughout sampling period within the lagoon system. Onset of rainfall and effluent discharge lead to the introduction of biodegradable contaminants which increased the total dissolved solid. At the peak of dry season, BOD and COD values were relatively high due to absence of rainfall which could have diluted it. $\mathrm{pH}$ values of $10.25 \pm 1.18$ recorded for the lagoon was higher than recommended limit of FME (Federal Ministry of Environment- 6.0-9.0). Pidgeon and Cains (1987) observed that High pH causes more carbonate and bicarbonate in water. And that organic acids resulting from decaying vegetation or biodegradable effluents might be responsible for low $\mathrm{pH}$ in most aquatic ecosystems as occasioned by the introduction from effluents resulting in $\mathrm{pH}$ of $6.17 \pm 0.32$ from our effluent sources. The level of oxygen depletion depends primarily on the amount of waste added, size, velocity and turbulence of the stream. Frequent deaths of fish in water in fact don't come from toxicity of matters, but from deficit of consumed oxygen from biological decomposition of pollutants. These pollutants affect the ecology of the lagoon negatively by altering the balance of other parameters, for instance: Alkalinity, $\mathrm{pH}$ and Biological Oxygen Demand. The effluents are highly alkaline and adding heavy metals to the lagoon in significant quantities (EPA, 2004, 2005).

Heavy metals values in Ologe lagoon were represented in the Tables 1. Zinc; which has the grand mean of 0.65 , Nickel has a grand mean of $38.18 \mathrm{mg} / \mathrm{l}$ and was high with Aluminium ranged between 177.43-201.88 mg/l, chromium ranged from 0.84-3.22 mg/l, Cupper ranged from 0.02-0.81 mg/l, but lead was not detected during the dry season (January and September, 2010). Conversely, the wet season present an interesting range of data with zinc ranging between 0.56-1.54 $\mathrm{mg} / \mathrm{l}$, Nickel was between $0.18-0.99 \mathrm{mg} / \mathrm{l}$, Aluminium ranged between $183.63199 .99 \mathrm{mg} / \mathrm{l}$, chromium ranged from $1.68-2.89 \mathrm{mg} / \mathrm{l}$, Cupper ranged from $0.49-0.61 \mathrm{mg} / \mathrm{l}$, and lead range between $0.18-0.30$ during the wet season. The mean values of the heavy metals in this study are below the (WHO, 2008) standards for drinking water. Also, the values are lower than the (USEPA, 1996) limits for the protection of aquatic ecosystems. The metallic contaminants in water of Ologe Lagoon have shown that the concentrations of these metals are still within the permissible limits but the bioaccumulations corroborate its histopathological implications.

Several live lesions have been established as tissue bio-makers consistent with the exposure of fish to effluent. These include pigmented macrophage aggregation (Patino et al., 2003; Fournie, 2001). Hepatocytes vacoulation (Stehr et al., 1998), multi foci coagulative necrosis and liver fatty degeneration. These biomarkers have been conclusively linked with certain factors: increase in age (Blazer et al., 2007), stress (Fournie, 2001) and degeneration relative to the level of exposure to PCBs (Stehr et al., 1998). The preponderance of these lesions in fish from contaminated waters bordering urban locations similar to our test location with Oreochromis niloticus has been firmly established and described in details for Winter flounder Pleuronectes americanus (Augspurger et al., 1994, Blazer et al., 2007; Murchelano et al., 1985) and conclusively establish a direct relationship between pervasiveness and severity of this lesion, hepatic neoplasm and levels of site contamination. There is a consensus however; that vacuolated hepatocytes are frequently found proximal to neoplasm and that tumour is usually associated with increasing numbers of vacuolated liver cells which were absent in the kidney with any lesions. The extent of deformities and cell injuries is also consistent with hepatotoxicant actions (Augspurger et al., 1994).

This study has established to some degree, the destructive and pathological potentials of industrial pollution on Ologe lagoon on the resident aquatic fauna and corroborates earlier work done by other researchers. And therefore proffers the recommendations: Manufacturing outfits should be made to install factory based recycling facilities especially for effluents, Industry must be encouraged to control pollution and develop technology that will recover and recycle their wastes, Conservation of existing threatened and endangered species through the in-situ and ex-situ conservative principles, Enforcing environment management system (EMS) tools in public and private establishment for effective environmental and cost oriented management e.g. EIA, and adopting the best available technology and introduction of tax rebates for industries for meeting pollution free standard. 


\section{Acknowledgement}

I have the pleasure of appreciating the efforts of Dr. Ben Emikpe, the chief pathologist in-charge of the Veterinary Pathology Department of the University of Ibadan, Nigeria; who took time out to analyze the slides and then interpreting the photomicrographs in details. Also, thanks to Mr. Ajepe; the chief Laboratory technologist for Department of Fisheries, Lagos State University, Lagos, Nigeria.

\section{References}

Adeboyejo, O. A., Clarke, E .O., Olarinmoye, O., Adebiyi, R. A., \& Unyinmadu, J. P. (2009). Temporal variation in the ecology of Kuramo water, Lagos Nigeria. The Zoologist, 7, 202-212.

Agboola, J. I., Anetekhai, M. A., \& Denloye, A. B. (2008). Aspect of ecology and fishes of Badagry creek, Nigeria. Journal of Fisheries and Aquatic Sciences, 3(3), 184-194. http://dx.doi.org/10.3923/jfas.2008.184.194

APHA. (1998). American Public Health Association; Water Works Association and water pollution control federation. Standard methods for the examination of water and waste water. (20th ed.). APHA. USA. p. 1220

Augspurger, T. P., Herman, R. L., Tanacredi, J. R., \& Hatfield, J. S. (1994). Liver lesions in winter flounder (Pseudopleuronectes americanus) from Jamaica bay, New York: Indications of environmental degradation. Estuaries, 17, 172-180. http://dx.doi.org/10.2307/1352566

Awosika, L., Osuntogun, N., Oyewo, E., \& Awobamise, A. (2002). Nigeria National Report Phase 1: Integrated Problem Analysis, Development and protection of the coastal and marine environment in Sub-Saharan Africa". Global Environment Facility MSP Sub-Saharan Project (GF/6010-0016), p. 88.

Blazer, V. S., Fournie, J. W., Wolf, J. C., \& Wolfe, M. J. (2007). Manual for the diagnostic analysis of proliferative liver and skin lesions in the brown bullhead Ameiurus nebulosus. pp. 2-3.

Clarke, E., Olarinmoye, O. M., Owodeinde, F. G., Adeboyejo, A. O., Jimoh, A., Akintola, S. L., \& Aderinola, O. J. (2008). The dynamics of Desmidacean populations in Ologe lagoon, Lagos, Nigeria. Journal of Cell and Animal Biology, 1, 21-30.

EPA. (2004). Primer for Municipal Wastewater Treatment Systems. Document No. EPA 832-R-04-001.

EPA. (2005). Protecting Water Quality from Agricultural Runoff. Fact Sheet No. EPA-841-F-05-001 March 2005.

FEPA. (1999). National guidelines and standards for water quality in Nigeria. p. 114. FEPA, Lagos, Nigeria.

Folmar, L.C., Denslow, N. D., Rao, V., Chow, M., Crain, D. A., \& Enblom, J. (1996). Vitellogenin induction and reduced serum testosterone concentrations in feral male carp (Cyprinus carpio) captured near a major metropolitan sewage treatment plant. Environ Health Perspect, 104, 1096-110. http://dx.doi.org/10.1289/ehp.961041096

Fournie, J. W., Summers, J. K., Courtney, L. A., Engle, V. D., \& Blazer, V. S. (2001). Utility of splenic macrophage aggregates as an indicator of fish exposure to degraded environments. J. Aqua. Anim. Health, 13, 105-116. http://dx.doi.org/10.1577/1548-8667(2001)013<0105:UOSMAA>2.0.CO;2

Harris, D. J., Poulsen, A. D. Frimodt-Moller, C., Preston, J., \& Cronk, C. B. (2000). Rapid radiation in Aframomum (Zingiberaceae): evidence from nuclear ribosomal DNA internal transcribed spacer (ITS) sequences. Edinburgh Journal of Botany, 57, 377-395. http://dx.doi.org/10.1017/S0960428600000378

Hogstrand, C., \& Haux, C. (1991). Binding and detoxification of heavy metals in lower vertebrates with reference to metallothionein. Comp. Biochem. Physiol, 100(1\&2), 137-141.

Javed, M. (2003). Relationship among water, sediments and plankton for the uptake and accumulation of heavy metals in river ravi. I.J.P. SCI., 2, 326-331.

Jobling, S., R., Williams, A., Johnson, A., \& Gross-Sorokin, M. (2006). Predicted exposures to steroid estrogens in U.K. rivers correlate with widespread sexual disruption in wild fish populations. Environ. Health. Perspect., 114, 32-39. http://dx.doi.org/10.1289/ehp.8050

Neskovic, N. K., Poleksic, V., Elezovic, I., \& Budimir, M. (1996). Biochemical and histopathological effects of glyphosate on carp Cyprinus carpio. Bulletin of Environment Contamination Toxicology, 56, 295-302. http://dx.doi.org/10.1007/s001289900044

Parrott, J. L., \& Blunt, B. R. (2005). Life-cycle exposure of fathead minnows (Pimephales promelas) to an 
ethinylestradiol concentration below $1 \mathrm{ng} / \mathrm{L}$ reduces egg fertilization success and demasculinizes males. Environmental Toxicology, 20(2), 131-141. http://dx.doi.org/10.1002/tox.20087

Patiño, R., Goodbred, S. L., Draugelis-Dale, R., Barry, C. E., Foott, J. S., Wainscott, M. R., \& Gross, T. S. (2003). Morphometric and histopathological parameters of gonadal development in adult common carp from contaminated and reference sites in lake Mead, Nevada. J. Aqua. Anim. Health, 15, 55-68. http://dx.doi.org/10.1577/1548-8667(2003)015<0055:MAHPOG $>2.0 . C O ; 2$

Pidgeon, R. W. J., \& Cains, S. C. (1987). Decomposition and Colonization by invertebrates of nature and exotic leaf material in a small stream in New England (Australia). Hydrobiologia, 77, 13-124.

Pinkney, A. E., Harshbarger, J. C., May, E. B., \& Reichert, W. L. (2004). Tumor prevalence and biomarkers of exposure and response in brown bullhead (Ameiurus nebulosus) from the Anacostia river, Washington, DC and Tuckahoe river, Maryland, USA. Environmental. Toxicol. Chem., 323, 638-647. http://dx.doi.org/10.1897/03-77

Seki, M., Narusaka, M., Ishida, J., Nanjo, T., \& Fujita, M. (2002). Monitoring the expression profiles of 7000 Arabidopsis genes under drought, cold, and high-salinity stresses using a full-length cDNA microarray. Plant J, 31, 279-292. http://dx.doi.org/10.1046/j.1365-313X.2002.01359.x

Stehr, C. M., Johnson, L. L., \& Myers, M. S. (1998). Hydropic vacoulation in the liver of three species of fish from the U.S. West coast: Lesion description and risk assessment associated wit $31 \mathrm{~h}$ contaminant exposure. Dis. Aqua. Orgarnisms, 32(2), 119-135. http://dx.doi.org/10.3354/dao032119

Thorpe, M. R., Ferrieri, A. P., Herth, M. M., \& Ferrieri, R. A. (2007). C-11-imaging: methyl jasmonate moves in both phloem and xylem, promotes transport of jasmonate, and of photoassimilate even after proton transport is decoupled. Planta, 226, 541-551. http://dx.doi.org/10.1007/s00425-007-0503-5

Vethaak, A. D., Van der Burg, B., \& Brouwer, A. D. (2000). Netherlands Research Platform on Endocrinedisrupting compounds (NEDiC). Endocrine-disrupting compounds: wildlife and human health risks. Proceedings of a 1-day symposium. In A. D. Vethaak, G. B. J. Rijs, B. Van der Burg \& A. Brouwer (Eds.). pp. 144-146. The Hague, The Netherlands.

USEPA. (1996). Water quality criteria documents for the protection of aquatic life in ambient water: 1995 Updates. United States Environmental Protection Agency, EPA 820-B-96-001, United States Environmental Protection Agency, September 1996, Office of Water Regulations and Standards. Washington.

WHO. (2008). Guidelines for Drinking Water Quality (3rd ed.), p. 668. Health Criteria and Supporting Information, WHO, Geneva. 